○浅見勝巳、中山博之、加藤敏江、加藤智浩、稲垣祥子、柴田康子、服部 琭 あいち小児保健医療総合センター

【はじめに】一側性難聴は言語発達・構音習得に影響しないとされてきたが、学校での座席 配慮の必要性や会議での会話の聞き取りにくさを訴える例も報告されており、やはり適切な 配慮を要する場面が存在すると思われる。しかし、こうした点についてのデー夕は少なく、 情報の収集を行うことが有用と考え、一側性難聴の日常生活でのハンディキャップ等に関す るアンケート調查を行った。

【対象】平成13年11月〜平成16年12月に、あいち小児保健医療総合センターを受診した一側 性難聴例で、1）レシーバ法での患側の聴力が $0.5 \cdot 1 \cdot 2 \cdot 4 \mathrm{kHz}$ で 40dBHL 以上、健側 の聴力が 20dBHL 以下、あるいは、2 ) スピーカ法(両耳聴) で $0.5 \cdot 1 \cdot 2 \cdot 4 \mathrm{kHz}$ が $20 \mathrm{dBHL}$ 以下で、 $\mathrm{ABR}$ 等の他覚的聴力検査から一側性難聴と考えられる、のいずれかの条件を満た す135例にアンケートを送り、48例から回答を得た（回収率 $35.6 \%$ )。

【結果】

\title{
(1) 発見経緯
}

0 歳での診断例が 13 例と最も多く、その内訳は外耳道閉鎖や小耳症から生後すぐ判明した 例 7 例、新生児聴覚スクリーニングによる発見 4 例、3 3 月健診での精検勧奨例 2 例であっ た。その他には 3 歳以降になって検診（ 3 歳児健診、就学前検診、学校検診）での発見例が 10例、家庭での様子で気づく例が17例（うち 9 例は電話使用時）と多かった。

(2) 失聴原因

48 例の一側性難聴中、左は 21 例、右は 27 例であった。失聴原因は不明との回答が 36 例と多 く、外耳道閉鎖や小耳例以外で原因について回答があったのは、中耳炎と回答した 1 例とム ンプスあるいは髄膜炎による失聴が疑われる 4 例の計 5 例であった。

（３）聴力変動、中耳炎罹患歴、聴覚管理

患側：聴力不変 47 例 悪化後回復 0 例 不明 1 例

健側：聴力不変 45 例 悪化後回復 2 例 不明 1 例

悪化後回復の 2 例はいずれも中耳炎による聴力変動と考えられた。中耳炎罹患歴は、なし 20 例、患側のみ 3 例、健側のみ 8 例、両側 15 例、一側のみ（左右不明） 1 例、未記入 1 例と 半数以上（48例中 27 例）が罹患歴ありとの回答だった。聴力管理は41例が定期検査を受けて いるが、観察（管理）中断が 6 例、不要と説明があったとするものが 1 例あった。

(4) 言語発達、構音への影響

言語発達：影響なし 32 例 不明 9 例 影響あり 6 例 未記入 1 例 構 音: 影響なし 34 例 不明 8 例 影響あり 3 例 未記入 3 例

子どもがまだ小さいのでわからない（不明）との回答もあったが、言語発達、構音ともに 影響なしとする回答が多かった。影響ありの回答は、ダウン症候群、ADHD、口蓋裂など言 語発達や構音習得に影響し得る他の要因を併せもつ例に多かったが、言語発達に影響ありと 回答した 6 例中 3 例は特に他の要因のないケースであった。

（5）日常生活や学校生活でのハンディキャップの有無 
「ハンディを全く感じない」は13例 $(27.1 \%)$ で、多くの例が程度の差はあるがハンディ を感じていた。ハンディキャップと配慮事項に関する回答の主なものを表 1 に示す。

（6）新生児期でのスクリーニングの必要性、一側性難聴発見に対する意見

新生児に対する聴覚スクリーニングの実施について

必要だと思う 43例、必要だとは思わない０例、未記入 3 例、その他 2 例

新生児聴覚スクリーニングでの一側性難聴発見について

良い 35例、良い面と悪い面がある 12 例、良くない 0 例

今回、新生児聴覚スクリーニングが難聴発見の契機となった例は回答を寄せた 48 例中 4 例 のみで、残る44例は無関係であるが、検査実施には肯定的であった。また、スクリーニング での一側性難聴発見を、良くないとする回答はなかった。しかし、「早期から必要な対応が できる」ことを良い点としてあげる回答が多かった一方で、早期の障害告知により「家族（特 に母親）が大きく動摇する」「子どもの将来に対し悲観的になりかねない」などの問題を指 摘する意見もあった（表 2 ）。

【考察】発見経緯は多岐にわたったが、多くが聴覚管理を継続していた。中耳炎に注意が必 要ではあるが、患側・健側ともに聴力は安定している例が多かった。言語発達や構音習得に は影響ないとの回答が多かったが、影響ありとの回答も少数ながら存在するので、言語発達 や構音習得についても経過観察が必要と思われる。さらに、48例中33例（68.8\%）が日常生 活でハンディを感じると回答しており、こうした実情や座席等の配慮についての情報提供が 有用であろう。また、新生児スクリーニングについては、発見時の家族の動摇や将来に対す る不安を訴える意見があり、結果の説明のみではなく、家族の抱える疑問に丁寧に対応する ことが重要であると思われる。

表 1 日常生活、学校生活上のハンディキャップと配慮事項（自由記述）

\begin{tabular}{|c|c|}
\hline \multicolumn{2}{|l|}{ 〈ハンディを感じること〉 } \\
\hline ・名前を呼んでも気づかないことがある & 6 例 \\
\hline ・患側からの話しかけに気つきにくい、あるいは間き取りにくい & 5 例 \\
\hline ·方向感がつかみにくい & 5 例 \\
\hline ・聞き返し、閻き間違いが多い & 5 例 \\
\hline ・雑音下での閗き取りがうまくできない事が多い & 4 例 \\
\hline \multicolumn{2}{|l|}{ 〈配慮していること〉 } \\
\hline 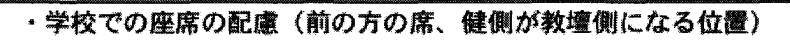 & 15 例 \\
\hline ・話しかけるときに閭こえる耳の側から & 3 例 \\
\hline ・車に気をつけるようによく注意している & 了例 \\
\hline •觙側耳の聴力を大事にする & 2 例 \\
\hline
\end{tabular}

表 2 一側性難聴が新生児スクリーニングで発見された場合（自由記述）

\begin{tabular}{|c|c|}
\hline \multicolumn{2}{|l|}{ <良い点 > } \\
\hline ・早くから必要な対応ができる（闑こえる側から話すなど） & 26例 \\
\hline ・早期治療に結びつく可能性がある & 12例 \\
\hline $\begin{array}{l}\text { ・いつから間こえなかったのか、なぜ早く気づかなかったのかと } \\
\text { 悔やまなくてよくなる }\end{array}$ & 2 例 \\
\hline 〈重い点〉 & \\
\hline $\begin{array}{l}\text { ・親が非常にショックを受ける、不安になる } \\
\text { ・治燎に結びつかないのであればあまり意味がない }\end{array}$ & $\begin{array}{r}13 \text { 例 } \\
1 \text { 例 }\end{array}$ \\
\hline
\end{tabular}

